\title{
Sinergi Project Based Learning dan Pembelajaran Bermakna Untuk Meningkatkan Hasil Belajar Matematika
}

\author{
Nuning Setyowati, Mawardi \\ 952017039@student.uksw.edu,mawardi@staff.uksw.edu \\ Pendidikan Profesi Guru Universitas Kristen Satya Wacana
}

\begin{abstract}
The Synergy Of Project Based Learning And Meaningful Learning To Increase Mathematics Learning Outcomes
\end{abstract}

\begin{abstract}
Mathematics was a lesson that must be published in all levels of education. So, the competence of mathematics should be understood by students. However, there were some problems on student's mathematics learning outcomes at the first semester in $4^{\text {th }}$ grade of SDN Gendongan 02. There were 39 students, but only 46\% (18 students) got score above minimum completeness criteria (KKM). While 54\% (21 students) got score under the KKM. The aims of this reseacrh was to increased the mathematics learning outcomes through the synergy of project based learning and meaningful learning. The type of this research was action research by using stringer model. This research held in two cycles with three stages. The stages consist of look, think, and act. The data collection used some instruments such as test, observation sheets, and field notes. The technique of data analysis used comparative descriptive technique. The subjects of the research were students in $4^{\text {th }}$ grade of SDN Gendongan 02. The result of completeness mathematics learning outcome in the first cycle was $72,5 \%$ and in the second cycle was $80 \%$. Student's mathematics learning outcomes in the second cycle were better than the mathematics learning outcomes in the first cycle. Based on the result, the synergy of project based learning and meaningful learning can increase mathematics learning outcomes. Therefore, the synergy of project based learning and meaningful learning were suggested to be applied at mathematics.
\end{abstract}

Keywords: project based learning, meaningful learning, mathematics learning outcome

Received date: 11 Mei 2018

\section{Article Info}

Revised date: 10 Agustus 2018
Accepted date: 21 September 2018

\section{PENDAHULUAN}

Matematika merupakan salah satu bidang studi yang ada pada semua jenjang pendidikan, mulai dari tingkat sekolah dasar hingga perguruan tinggi. Bahkan matematika diajarkan di taman kanak-kanak secara informal (Susanto, 2013: 183). Berdasarkan Permendikbud No. 21 Tahun 2016 tentang Standar Isi, salah satu kompetensi yang ingin dicapai dalam muatan pelajaran matematika di tingkat pendidikan dasar adalah menunjukkan sikap positif bermatematika: logis, cermat dan teliti, jujur, bertanggung jawab, dan tidak mudah menyerah dalam menyelesaikan masalah, sebagai wujud implementasi kebiasaan dalam inkuiri dan eksplorasi matematika, serta memiliki rasa ingin tahu, semangat belajar yang kontinu, percaya diri, dan ketertarikan pada matematika melalui pengalaman belajar (2016: 111). Selain itu, dalam Permendikbud No. 24 Tahun 2016 tentang Kompetensi Inti dan Kompetensi Dasar, ruang lingkup matematika adalah: (1) bilangan; (2) geometri; dan (3) statistika (2016: 111-112).

Berdasarkan kompetensi yang ingin dicapai dan ruang lingkup muatan pelajaran matematika, diharapkan peserta didik mampu berpikir logis, analitis, sistematis, kritis, dan kreatif serta mampu bekerjasama. Selain itu, pembelajaran juga mengacu pada pemberlakuan kurikulum 2013 yang memiliki prinsip pada pembelajaran matematika, diantaranya pembelajaran mulai dari pengamatan permasalahan konkret, kemudian menuju ke semi konkret, dan pada akhirnya abstraksi permasalahan, serta rumus harus diturunkan oleh peserta didik, peserta didik tidak hanya bisa menggunakan atau menghafal rumusnya saja tetapi mengetahui asal usulnya (Kemendikbud: 2014: 72). Tuntutan 
perkembangan zaman dan upaya peningkatan mutu pendidikan dalam kurikulum yang berlaku saat ini, bahwa peserta didik diajarkan untuk memperoleh pengetahuan secara HOTS (High Order Thinking Skills) salah satunya menekankan pada pertanyaan yang membutuhkan pemikiran mendalam, bukan sekedar hafalan.

Oleh karena itu, dalam pembelajaran matematika hendaknya dimulai dengan pengenalan masalah yang berkaitan dengan kehidupan sehari-hari. Sehingga pembelajaran hendaknya bersifat kontekstual dan peserta didik dapat menemukan sendiri konsep matematika yang dipelajari. Sehingga tidak semata-mata memahami konsep yang sudah ada, tetapi mampu berproses untuk mendapatkan konsep-konsep tersebut. Selain itu, pembelajaran matematika tidak hanya fokus pada pemerolehan pengetahuan saja, akan tetapi menanamkan sikap yang dapat diterapkan dalam pemecahan masalah kehidupan sehari-hari, serta keterampilan terkait pemecahan masalah tersebut. Pembelajaran matematika harus dilaksanakan dengan cara yang menyenangkan untuk membangkitkan ketertarikan peserta didik terhadap matematika melalui berbagai pengalaman belajar.

Mengacu pada pelaksanaan kurikulum yang berlaku yaitu kurikulum 2013, SDN Gendongan 02 sudah berusaha melaksanakan pembelajaran yang sesuai dengan tuntutan kurikulum. Hal tersebut relevan dengan visi sekolah yaitu "berprestasi, bertaqwa, terampil yang dijiwai oleh nilai-nilai budaya dan karakter bangsa". Visi ini didukung dengan misi pertama, yang berbunyi "melaksanakan pembelajaran yang PAKEM dalam rangka untuk mencapai prestasi dengan dilandasi nilai-nilai budaya dan karakter bangsa". Guru kelas 4 SDN Gendongan 02 juga turut mensukseskan visi dan misi sekolah dengan berusaha meciptakan suasana pembelajaran matematika yang menyenangkan dan menggunakan berbagai strategi.

Namun perolehan hasil belajar matematika masih jauh dari harapan. Senada dengan pernyataan tersebut, hasil belajar matematika pada semester 1 peserta didik kelas 4 SDN Gendongan 02 juga mengalami permasalahan. Dari 39 peserta didik hanya 46\% (18 peserta didik) yang mendapat nilai di atas Kriteria Ketuntasan Minimal (KKM), dan 54\% (21 peserta didik) lainnya mendapat nilai di bawah KKM. Hal ini relevan dengan hasil survey TIMSS (Trend in International Mathematics and Science Study) pada tahun 2015 yang menunjukkan perolehan skor peserta didik Indonesia menempati peringkat ke 45 dari 50 negara.

Berdasarkan hasil refleksi bersama guru kelas 4 SDN Gendongan 02 teridentifikasi beberapa permasalahan, antaralain: (1) peserta didik kurang tertarik dengan matematika; (2) peserta didik cenderung malas menyelesaikan tugas pada pembelajaran matematika yang berupa soal cerita; (3) pembelajaran bersifat deduktif, artinya pemerolehan konsep diajarkan di awal pembelajaran bukan didapatkan melalui pengalaman pembelajaran, pada pembelajaran matematika lebih sering diajarkan rumusnya terlebih dahulu untuk memecahkan masalah-masalah pada latihan soal tanpa diajarkan darimana rumus itu diperoleh; (4) sering menggunakan metode menghafal rumus, sedangkan ingatan peserta didik terbatas; (5) permasalahan dalam pembelajaran matematika kurang kontekstual; dan (6) peserta didik cenderung lebih sering memperoleh materi dari aktivitas mendengar dan melihat, belum sampai aktivitas melakukan.

Menindaklanjuti permasalahan tersebut, peneliti bersama tim kolaborator menyimpulkan permasalahan tersebut termasuk permasalahan yang mendesak dan penting untuk dipecahkan. Berpijak pada teori konstruktivisme, salah satu model pembelajaran inovatif yang sesuai untuk memecahkan permasalahan tersebut dan berpusat pada peserta didik adalah project based learning. Project based learning merupakan model pembelajaran yang menggunakan projek/kegiatan sebagai media. Guru menugaskan peserta didik untuk melakukan eksplorasi, penilaian, interpretasi, sintesis, dan informasi untuk menghasilkan berbagai bentuk hasil belajar (Hosnan, 2014: 319). Cord et al dalam Rais (2010: 4) menyatakan bahwa project based learning merupakan model pembelajaran yang inovatif yang menekankan pada pembelajaran kontekstual melalui kegiatan-kegiatan yang kompleks seperti memberi kebebasan peserta didik untuk bereksplorasi merencanakan aktivitas belajar, melaksanakan projek secara kolaboratif, dan pada akhirnya menghasilkan produk.

George Lucas Educational Foundation (2007) menyatakan bahwa project based learning penting diterapkan dalam pembelajaran karena memberikan banyak manfaat terutama untuk menyiapkan peserta didik yang mampu memecahkan masalah yang sangat kompleks dan memiliki keterampilan dasar (membaca, menulis, dan matematika) serta keterampilan abad 21 (kerja tim, pemecahan masalah, melakukan penelitian, manajemen waktu, membuat informasi, memanfaatkan alat teknologi). Keterampilan abad 21 yang dimaksud antara lain: (1) tanggung jawab individu dan 
kelompok; (2) perencanaan, pemikiran kritis, penalaran, dan kreativitas; (3) keterampilan komunikasi yang kuat, baik utuk kebutuhan interpersonal dan presentasi; (4) pemahaman lintas budaya dan pengambilan keputusan; serta (5) memilih dan menggunakan alat tertentu untuk menyelesaikan tugas.

Penelitian yang relevan dengan penelitian ini antara lain penelitian yang dilakukan oleh Ross et Al dalam John W. Thomas (2000: 10), Umi Faizah (2015: 24), Tafakur (2015: 117) yang menunjukkan bahwa project based learning dapat meningkatkan hasil belajar peserta didik.

Dari beberapa penelitian yang telah dilakukan, belum terdapat penelitian yang mengkombinasikan model project based learning dengan pembelajaran bermakna. Sedangkan pada hakikatnya pembelajaran bermakna berdasarkan perspektif Ausubel dalam Aisyah (2015: 2) merupakan faktor penting yang mempengaruhi keberhasilan pembelajaran. Keberhasilan pembelajaran tidak hanya berorientasi pada hasil belajar saja tapi dapat dicapai dengan memperhatikan kebermaknaan proses pembelajarannya.

Adapun rumusan masalah dari penelitian ini adalah "apakah sinergi project based learning dan pembelajaran bermakna dapat meningkatkan hasil belajar matematika?". Berdasarkan rumusan masalah tersebut, penelitian ini bertujuan untuk meningkatkan hasil belajar matematika melalui sinergi project based learning dan pembelajaran bermakna. Manfaat penelitian ini adalah sebagai berikut: (1) secara teoretis, penelitian ini dapat bermanfaat untuk menambah referensi bagi perkembangan ilmu pengetahuan dan menambah pendekatan pembelajaran yang dapat meningkatkan kebermaknaan dan hasil belajar pada pembelajaran matematika, terutama yang dapat membantu peserta didik agar dapat membangun pengetahuannya sendiri berdasarkan pengalaman belajar melalui pembelajaran yang bermakna; (2) secara praktis, manfaat penelitian bagi peneliti adalah menambah wawasan, pengetahuan, dan keterampilan peneliti terkait penelitian tentang project based learning; bagi guru menambahkan alternatif bagi guru untuk menciptakan suasana pembelajaran yang aktif, partisipatif, kondusif, dan menyenangkan, serta mendapat hasil yang optimal, sehingga guru dapat memaksimalkan perannya sebagai fasilitator, inovator, motivator, evaluator, dan juga informator; serta memudahkan peserta didik untuk dapat membangun sendiri pegetahuannya berdasarkan pengalaman belajar yang bermakna.

Berdasarkan ulasan latar belakang tersebut, peneliti bersama tim kolaborator melakukan penelitian tindakan kelas dengan judul "Sinergi Project Based Learning dan Pembelajaran Bermakna untuk Meningkatkan Hasil Belajar Matematika".

\section{KAJIAN PUSTAKA}

\section{Hasil Belajar Matematika}

Walker (1955: 115) berpendapat bahwa "Mathematics maybe defined as the study of abstract science of space and number", matematika dapat didefinisikan sebagai ilmu abstrak mengenai ruang dan bilangan. Senada dengan pendapat Johson dan Myklebust dalam Adurrahman (2003: 252) dalam Sundayana (2015: 2) yang mengemukakan bahwa matematika merupakan bahasa simbolis yang mempunyai fungsi praktis untuk mengekspresikan hubungan-hubungan kuantitatif dan keruangan.

Sehingga dapat disimpulkan bahwa matematika merupakan ilmu yang membekali peserta didik untuk dapat berpikir logis, analitis, sistematis, kritis, dan kreatif. Piaget membagi perkembangan kognitif manusia menjadi empat tahap yaitu tahap sensori motor (0-2 tahun), tahap pra-operasional (27 tahun), tahap operasional konkret (7-11 tahun), dan tahap operasional formal (>11 tahun). Berdasarkan teori tersebut, peserta didik tingkat sekolah dasar berada pada tahap operasional konkret. Pada tahap ini, peserta didik membuat kesimpulan dari situasi dunia nyata dengan menggunakan benda konkret yang diperoleh dari kehidupan sehari-hari. Peserta didik SD pada umunya lebih cepat memahami materi pembelajaran, apabila materi tersebut diperoleh dari proses mengkonstruksi pengetahuan dari pengalamannya sendiri.

Oleh karena itu, pembelajaran matematika di SD menekankan pada pemerolehan pengetahuan berdasarkan pengalaman belajar yang kontekstual, dimulai dari pengetahuan yang konkret. Jadi, pembelajaran matematika hendaknya dirancang dan dikaitkan dengan situasi suasana di lingkungan sekitar peserta didik.

Bloom (1956) mengklasifikasikan hasil belajar menjadi tiga ranah, yaitu ranah pengetahuan (cognitive domain), ranah sikap (affective domain), dan ranah keterampilan (psychomotor domain). Ranah pengetahuan terdiri dari empat kategori, yaitu pengetahuan tentang fakta, prosedural, konsep, 
dan prinsip. Sedangkan pada ranah keterampilan terdiri dari empat kategori, keterampilan untuk berpikir atau keterampilan kognitif, keterampilan untuk bertindak atau keterampilan motorik, keterampilan bereaksi atau bersiap, dan keterampilan berinteraksi. Sementara Rifa'i dan Anni (2012: 69) menyatakan bahwa hasil belajar merupakan perubahan perilaku yang diperoleh peserta didik setelah mengalami kegiatan belajar.

Sedangkan Gagne (dalam Suprijono, 2012: 5-6) menyatakan bahwa hasil belajar dapat berupa: (1) informasi verbal yaitu kapasitas mengungkapkan pengetahuan dalam bentuk bahasa, baik lisan maupun tertulis, kemampuan merespon terhadap rangsangan spesifik; (2) keterampilan intelektual yaitu kemampuan mempresentasikan konsep dan lambang, yang terdiri dari kemampuan mengkategorisasi, kemampuan analitis-sintesis fakta-konsep dan mengembangkan prinsip-prinsip keilmuan; (3) strategi kognitif yaitu kecakapan menyalurkan dan mengarahkan aktivitas kognitifnya sendiri; (4) keterampilan motorik yaitu kemampuan melakukan serangkaian gerak jasmani dalam urusan dan koordinasi, sehingga terwujud otomatisme gerak jasmani; dan (5) sikap adalah keampuan menerima atau menolak objek berdasarkan penilaian terhadap objek tersebut.

Berdasarkan uraian di atas, dapat disimpulkan bahwa hasil belajar dalam pembelajaran matematika merupakan pencapaian yang diperoleh peserta didik setelah melalui serangkaian proses belajar yang meliputi ranah sikap, pengetahuan, dan keterampilan. Pemerolehan hasil belajar ini bergantung pada pelaksanaan pembelajaran. Untuk mencapai hasil belajar yang maksimal dapat diusahakan dengan dilaksanakannya pembelajaran matematika yang menyenangkan dan kontekstual.

\section{Project Based Learning}

Project based learning merupakan model pembelajaran yang menggunakan projek/kegiatan sebagai media. Guru menugaskan peserta didik untuk melakukan eksplorasi, penilaian, interpretasi, sintesis, dan informasi untuk menghasilkan berbagai bentuk hasil belajar (Hosnan, 2014: 319).

Adapun sintak model pembelajaran project based learning menurut Lucas (2007) antara lain: (1) start with the essential question (menentukan pertanyaan mendasar); (2) design a plan for the project (menyusun perencanaan projek); (3) create a schedule (menyusun jadwal); (4) monitor the student and the progress of project (memonitor peserta didik dan kemajuan projek); (5) assess the outcome (menilai hasil); dan (6) evaluate the experience (evaluasi pengalaman).

Project based learning memiliki kelebihan dan kelemahan. Kelebihan model pembelajaran project based learning menurut Kurniasih dalam Nurfitrianti (2016: 7) antara lain: (1) meningkatkan motivasi belajar peserta didik untuk belajar; (2) meningkatkan kemampuan peserta didik dalam memecahkan masalah; (3) menjadikan peserta didik aktif dan dapat memecahkan permasalahan yang kompleks; (4) meningkatkan kolaborasi antar peserta didik; (5) mendorong peserta didik untuk meningkatkan keterampilan berkomunikasi; (6) memberikan pengalaman kepada peserta didik agar dapat membagi tugas dan mengelola bahan serta waktu dalam menyelesaikan projek; (7) membuat suasana pembelajaran menjadi menyenangkan.

Di samping itu, menurut Sani dalam Nurfitriyanti (2016: 7) project based learning memiliki beberapa kelemahan yaitu: (1) membutuhkan waktu yang cukup lama untuk menghasilkan produk; (2) membutuhkan lebih banyak biaya; dan (3) membutuhkan fasilitas yang memadai. Namun kelemahan tersebut dapat diatasi dengan memanajemen waktu dengan baik pada fase penjadwalan dan monitoring kemajuan projek, guru dapat mengingatkan waktu yang sudah ditentukan kepada peserta didik. Fasilitas yang dibutuhkan hendaknya dipersiapkan terlebih dahulu sesuai dengan kondisi sekolah dan peserta didik.

\section{Pembelajaran Bermakna}

Harpaz (2000: 3) menyatakan bahwa pembelajaran bermakna adalah suatu proses dimana peserta didik membangun pemahamannya dan menjadikan dasar untuk memahami pengetahuan selanjutnya lebih lanjut. Pembelajaran bermakna berdasarkan perspektif Ausubel dalam Aisyah (2015: 2) merupakan faktor penting yang mempengaruhi keberhasilan pembelajaran. Mulyasa (2015: 100102) menyatakan terdapat beberapa prosedur yang dapat dirancang oleh guru untuk mengembangkan pembelajaran bermakna, yaitu: (1) pemanasan dan apersepsi yang dapat dilakukan bersama peserta didik, pembelajaran dengan hal-hal yang diketahui peserta didik, memotivasi dengan bahan ajar yang menarik dan berguna bagi kehidupan peserta didik, serta menggerakkan peserta didik agar tertarik dan bersemangat untuk mengetahui hal-hal baru; (2) eksplorasi yang dapat ditempuh dengan 
memperkenalkan kompetensi yang harus dikuasai peserta didik, mengaitkan kompetensi yang baru dengan kompetensi yang telah dikuasai peserta didik sebelumnya, serta menggunakan variasi metode yang tepat; (3) konsolidasi pembelajaran yang dapat dilakukan dengan melibatkan peserta didik secara aktif dalam menafsirkan dan memahami materi atau kompetensi baru serta memecahkan masalah (problem solving), membuat penekanan pada kaitan struktural (kaitan dengan berbagai aspek kehidupan nyata), serta memilih metode yang tepat; (4) pembentukan sikap, kompetensi, dan karakter yang dapat dicapai dengan memotivasi peserta didik untuk menerapkan atau mempraktikkan langsung konsep, pengertian, kompetensi, dan karakter yang dipelajarinya dalam kehidupan sehari-hari; dan (5) penilaian formatif yang dilakukan melalui pengembangan sistem penilaian yang sesuai serta menggunakannya sebagai alat evaluasi untuk menganalisis kelemahan sebagai upaya menemukan solusi atau tindak lanjut.

Beberapa penelitian yang mendukung penelitian ini antara lain yang dilakukan oleh Ardiana Pangestika Konita, Imam Suyanto dan Suhartono (2015); Hesti Rahmawati, Syahrilfuddin, dan Eddy Noviana (2016); Lutfiana Indah Sari, Hari Satrijono, dan Sihono (2015); Kun Sasanti Sitaresmi, Sulistyo Saputro, dan Suryadi Budi Utomo (2017); serta Ardhyan Ramadhany, Arif Purnomo, dan Andy Suryadi (2016) yang menunjukkan bahwa model project based learning dapat meningkatkan hasil belajar peserta didik. Sedangkan penelitian yang mendukung dilaksanakannya pembelajaran bermakna antara lain yang dilakukan oleh Dwi Wahyuning Aisyah, Muhana Gipayana, dan Ery Tri Dajtmiko R.W.W. (2017); Nur Ridho (2011), dan Yoram Harpaz.

Berdasarkan ulasan di atas, belum terdapat satupun yang memperhatikan proses pembelajaran bermakna dalam muatan pelajaran matematika. Oleh karena itu, peneliti berusaha menciptakan pembelajaran yang dapat meningkatkan hasil belajar matematika dengan menerapkan sinergi project based learning dan pembelajaran bermakna, adapun implementasinya dalam pembelajaran adalah sebagai berikut.

Tabel 1.

Sinergi Project Based Learning dan Pembelajaran Bermakna

\begin{tabular}{|c|c|c|}
\hline $\begin{array}{c}\text { Sintak Project Based Learning } \\
\text { (George Lucas Educational } \\
\text { Foundation, 2005) }\end{array}$ & $\begin{array}{l}\text { Pembelajaran Bermakna } \\
\text { (Mulyasa, 2015: 100-102) }\end{array}$ & $\begin{array}{l}\text { Sinergi Project Based Learning dan } \\
\text { Pembelajaran Bermakna }\end{array}$ \\
\hline $\begin{array}{l}\text { 1. Menentukan pertanyaan } \\
\text { mendasar }\end{array}$ & $\begin{array}{l}\text { 1.Pemanasan - Apersepsi } \\
\text { 2. Eksplorasi }\end{array}$ & $\begin{array}{l}\text { 1.Pemanasan - Apersepsi - Menentukan } \\
\text { pertanyaan mendasar. }\end{array}$ \\
\hline $\begin{array}{l}\text { 2. Menyusun perencanaan } \\
\text { projek }\end{array}$ & $\begin{array}{l}\text { 3. Konsolidasi } \\
\text { 4. Pembentukan sikap dan }\end{array}$ & $\begin{array}{l}\text { 2. Menyusun perencanaan projek - Eksplorasi } \\
\text { - Konsolidasi. }\end{array}$ \\
\hline 3. Menyusun jadwal & perilaku & 3. Menyusun jadwal. \\
\hline $\begin{array}{l}\text { 4. Memonitor peserta didik } \\
\text { dan kemajuan projek } \\
\text { 5. Menilai hasil } \\
\text { 6. Evaluasi pengalaman }\end{array}$ & 5.Penilaian formatif & $\begin{array}{l}\text { 4. Pembentukan sikap dan perilaku dalam } \\
\text { pengerjaan projek - memonitor peserta didik } \\
\text { dan kemajuan projek. } \\
\text { 5. Menilai hasil. } \\
\text { 6. Evaluasi pengalaman. } \\
\text { 7. Penilaian formatif. }\end{array}$ \\
\hline
\end{tabular}

Joyce (2009: 16-19) menyatakan terdapat lima unsur pembelajaran, salah satunya adalah dampak instruksional (instructional effect) dan dampak pengiring (nuturent effect). Dampak instruksional merupakan hasil belajar yang ingin dicapai ataupun yang berkaitan dengan materi pembelajaran. Sedangkan dampak pengiring merupakan hasil belajar iringan yang muncul sebagai akibat dari penggunaan model pembelajaran tertentu. Pada penelitian ini, dampak instruksional yang ingin dicapai adalah perolehan pengetahuan dan keterampilan peserta didik tentang diagram batang dan sudut pada bangun datar. Adapun untuk domain sikap, karakter yang ingin dibentuk adalah kerjasama, disiplin, dan tanggung jawab.

Berdasarkan ulasan di atas, didapatkan hipotesis penelitian yaitu sinergi project based learning dan pembelajaran bermakna dapat meningkatkan hasil belajar matematika. 


\section{METODE PENELITIAN}

Penelitian ini merupakan penelitian tindakan kelas yang dilaksanakan pada semester genap tahun ajaran 2017/2018. Penelitian dilaksanakan di kelas 4 SDN Gendongan 02. Adapun subjek penelitian terdiri dari 40 peserta didik. Berikut desain penelitian tindakan kelas menggunakan model stringer (Yaumi, 2014: 45):

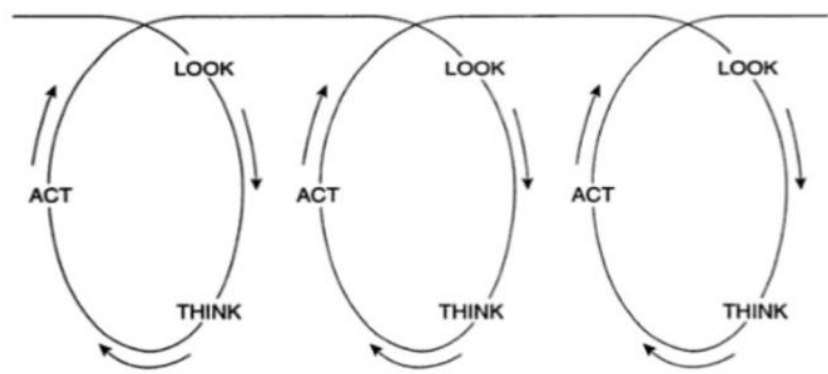

Gambar 1.

Model Stringer dalam PTK

Berdasarkan desain penelitian di atas, penelitian dilaksanakan selama 2 siklus. Sebelum pelaksanaan siklus diadakan observasi (look), kemudian peneliti beserta tim kolaborator melakukan refleksi dan memikirkan alternatif pemecahan masalahnya (think), kemudian melakukan tindakan (act) berupa pelakanaan siklus 1. Setelah dilakukan siklus 1, kemudian peneliti melihat hasilnya baik pelaksanaan tindakan maupun hasil belajar peserta didik (look), kemudian memikirkan langkah perbaikan untuk siklus 2 (think), berdasarkan hasil pemikiran, siklus 2 siap dilaksanakan (act).

Variabel dalam penelitian dibedakan menjadi dua, yaitu variabel bebas berupa sinergi project based learning dan pembelajaran bermakna, dan variabel terikat berupa hasil belajar matematika. Teknik pengumpulan data hasil belajar menggunakan tes tertulis berbentuk isian singkat dan uraian. Adapun indikator keberhasilah dalam penelitian ini adalah ketuntasan hasil belajar peserta didik mencapai $75 \%$.

Teknik analisis data dalam penelitian ini menggunakan deskriptif komparatif, yaitu dengan menghitung persentase ketuntasan hasil belajar peserta didik pada siklus 1 kemudian dibandingkan dengan persentase ketuntasan hasil belajar peserta didik pada siklus 2 .

\section{HASIL PENELITIAN DAN PEMBAHASAN}

\section{Hasil Penelitian}

Data hasil belajar terdiri dari data hasil belajar peserta didik pada siklus 1 dan siklus 2 . Setelah diberikan tindakan berupa penerapan sinergi project based learning dan pembelajaran bermakna, diperoleh hasil belajar matematika berikut ini.

Tabel 2.

Hasil Belajar Matematika

\begin{tabular}{cccccc}
\hline \multirow{2}{*}{ No. } & \multirow{2}{*}{ Kategori } & \multicolumn{2}{c}{ Siklus 1 } & \multicolumn{2}{c}{ Siklus 2 } \\
\cline { 3 - 6 } & & Banyak Peserta didik & Persentase & Banyak Peserta didik & Persentase \\
\hline 1. & Tuntas & 29 & $72,5 \%$ & 32 & $80 \%$ \\
\hline 2. & Tidak Tuntas & 11 & $27,5 \%$ & 8 & $20 \%$ \\
\hline
\end{tabular}

Perolehan ketuntasan hasil belajar matematika peserta didik pada siklus 1 lebih besar dibanding dengan hasil belajar prasiklus $(72,5 \%>46 \%)$. Begitu pula dengan ketuntasan hasil belajar matematika peserta didik pada siklus 2 lebih besar dibanding dengan hasil belajar siklus 1 $(80 \%>72,5 \%)$. Hasil penelitian tersebut menunjukkan adanya peningkatan hasil belajar matematika setelah dilaksanakan pembelajaran menggunakan sinergi project based learning dan pembelajaran bermakna. 


\section{Pembahasan}

Siklus 1 dilaksanakan selama dua pertemuan yaitu pada tanggal 22 dan 23 Maret 2018 selama 6 jam pelajaran. Pembelajaran dilaksanakan berdasarkan langkah-langkah yang telah disusun meskipun masih terdapat tahap yang tidak terlaksana. Tahap yang tidak terlaksana tersebut adalah tahap penyusunan jadwal. Pembelajaran dimulai dari pemanasan dengan mengikuti senam anak. Selanjutnya apersepsi - pertanyaan mendasar, tentang alat pengukur tinggi dan berat badan, serta data diri peserta didik. Peserta didik dikelompokkan menjadi 4 kelompok. Pada tahap menyusun perencanaan projek - eksplorasi - konsolidasi berisi mengenai cara peserta didik mendapatkan data dirinya dan manfaat mengetahui data tersebut. Projek yang dilaksanakan berupa pengumpulan data diri peserta didik kelas 4, yaitu tinggi badan, berat badan, muatan pelajaran kesukaan, dan bulan kelahiran serta penyajian data dalam bentuk diagram batang. Setelah menentukan projek yang akan dilaksanakan, peserta didik berkelompok sesuai pembagian dan membagi tugas dengan adil. Kegiatan dirancang agar peserta didik bersemangat dan bermakna, karena hal-hal yang dibahas dekat dengan kehidupan peserta didik. Hal ini relevan dengan hasil temuan penelitian Sari (2015: 13) yang menyatakan bahwa pada pelaksanaan pembelajaran menggunakan model project based learning peserta didik sangat antusias, senang, dan terlibat secara aktif dalam kegiatan pembelajaran.

Setelah tahapan tersebut, seharusnya terdapat tahap menyusun jadwal untuk penyelesaian projek yang akan dikerjakan, tetapi penjadwalan ini belum dilaksanakan secara tegas, hanya disampaikan teknik pelaksanaannya saja tanpa ditentukan alokasi waktu tahapan penyelesaian projek. Selanjutnya pembelajaran berpusat pada kegiatan pengumpulan data peserta didik dan pengolahan data serta penyajiannya dalam bentuk diagram batang. Pada tahap ini guru harus mampu menciptakan keadaan yang mampu menjadikan peserta didik sebagai pembelajar yang mandiri. Hal ini sesuai dengan pendapat Rahmawati (2016: 4) yang menyatakan bahwa guru berperan sebagai fasilitator dan motivator.

Setelah projek selesai, peserta didik diminta untuk mempresentasikan hasil pekerjaannya. Dalam proses presentasi, peserta didik yang maju membuat pertanyaan agar dijawab oleh teman yang lain. Hal ini membantu peserta didik untuk dapat mengasah kemampuan menanya mereka. Selain itu, juga melatih peserta didik untuk berkomunikasi dengan pihak lain, hal ini sesuai dengan Sani (2014: 177) yang menyatakan bahwa salah satu manfaat project based learning adalah membantu peserta didik untuk mempraktikkan kemampuannya dalam berkomunikasi. Setelah selesai presentasi, guru memberikan tangapan dan apresiasi, serta mengevaluasi pengalaman.

Pembelajaran pada siklus 1 berjalan cukup baik, diikuti peserta didik dengan antusias dan aktif dalam menanggapi pertanyaan dan kerja kelompok. Untuk mengukur hasil belajar, peserta didik diberikan tes formatif untuk dikerjakan secara individu. Dari hasil tes formatif pada siklus 1 didapatkan ketuntasan sebesar 72,5\% dan tindakan yang dilakukan mendapat skor 78,6\% yang termasuk dalam kategori baik. Hasil ketuntasan belajar masih di bawah 75\%, hal ini diduga karena tahap penyusunan jadwal tidak dilaksanakan, dan dalam presentasi pertanyaan yang diberikan baru sebatas menemukan dan membandingkan data dalam diagram batang, belum sampai menganalisis data.

Berdasarkan data hasil belajar dan observasi tindakan pada siklus 1, kemudian diadakan refleksi bersama tim kolaborator. Kekurangan pada siklus 1 berupa tidak terlaksananya tahap penyusunan jadwal yang kemudian diperbaiki pada siklus 2. Siklus 2 dilaksanakan selama 6 jam pelajaran pada dua pertemuan, yaitu tanggal 12 dan 13 April 2018. Materi pada siklus 2 ini adalah sudut pada bangun datar.

Pembelajaran diawali dengan pemanasan berupa senam anak, kemudian dilanjutkan dengan apersepsi dan menentukan pertanyaan mendasar yaitu tanya jawab mengenai kegunaan busur derajat, lalu menentukan letak sudut, nama, dan ukurannya pada gabungan bangun datar yang berbentuk rumah. Memasuki kegiatan inti, pada tahap ini menyusun perencanaan projek - eksplorasi konsolidasi, peserta didik bersama guru menentukan projek yang akan dibuat berupa pembuatan gabungan bangun datar yang disusun sehingga berbentuk rumah, kemudian peserta didik menentukan nama pada tiap-tiap sudut, mengukurnya, lalu menentukan jenisnya berdasarkan hasil pengukuran sudut menggunakan busur derajat. Hal ini bermanfaat untuk menjadikan peserta didik mampu menentukan langkah dalam penyelesaian tugas. Manfaat ini sejalan dengan temuan pada penelitian yang dilakukan oleh Faizah (2015: 12) yang menyatakan bahwa pada tahap menentukan pertanyaan 
mendasar terbukti peserta didik mampu merumuskan masalah dan mengumpulkan data. Peserta didik dikelompokkan menjadi 8 kelompok, masing-masing 5 peserta didik.

Tahap selanjutnya yaitu menyusun jadwal penyelesaian projek, projek akan dilaksanakan selama 2 pertemuan, pada pertemuan pertama langkah pembelajaran dilaksanakan sampai penyusunan bangun datar, dan dilanjutkan pada pertemuan kedua untuk tahap penemuan sudut dan seterusnya. Setelah menyusun jadwal, peserta didik mulai mengerjakan projek dengan didampingi oleh guru. Guru bertugas memantau kinerja peserta didik dan kemajuan projek. Saat pelaksanaan tahap ini, aturan-aturan dalam pengerjaan projek mulai dilaksanakan guna pembentukan sikap. Setiap peserta didik menjadi disiplin dan bertanggungjawab untuk menyelesaikan tugasnya masing-masing. Karakter yang dikembangkan ini relevan dengan karakter yang dikembangkan pada penelitian yang dilakukan oleh Mutaqin. Salah satu hasil penelitian tersebut menyatakan bahwa nilai-nilai yang dikembangkan dari pelaksanaan project based learning adalah peduli, tanggung jawab, dan disiplin (Mutaqin, 2014: 190).

Setelah projek selesai, peserta didik mempresentasikan hasil pekerjaannya. Dalam presentasi, peserta didik dilatih untuk dapat berkomunikasi dengan baik. Guru dan peserta didik yang lain memberikan tanggapan atas hasil kerja kelompok, dan saran perbaikan untuk pembelajaran berikutnya. Setelah pembelajaran, peserta didik diberikan tes formatif untuk dikerjakan secara individu.

Berdasarkan hasil tes formatif pada siklus 2, ketuntasan hasil belajar matematika meningkat menjadi $80 \%$ dan sudah memenuhi indikator keberhasilan. Hal ini diduga karena pelaksanaan tindakan mencapai $92,8 \%$ termasuk kategori sangat baik. Selain berdampak pada peningkatan hasil belajar, pembelajaran menggunakan sinergi project based learning dan pembelajaran bermakna memberikan beberapa dampak pengiring yang diketahui melalui teknik observasi, diantaranya: (1) peserta didik bersemangat dalam mengikuti pembelajaran matematika; (2) kreativitas, kemampuan berpikir kritis, kemampuan berkolaborasi, dan kemampuan berkomunkasi peserta didik terbangun dengan adanya projek yang harus mereka kerjakan; (3) meningkatnya kemampuan mengorganisir kelompok karena peserta didik harus dapat mengatur pembagian tugas agar projek dapat terselesaikan dengan baik; (4) menumbuhkan jiwa kompetitif antar peserta didik supaya menjadi kelompok yang terbaik; serta (5) pembelajaran lebih bermakna dan memberikan arti mendalam bagi peserta didik dan guru.

Pembelajaran matematika dengan penerapan sinergi project based learning dan pembelajaran bermakna memberikan sumbangsih terhadap perkembangan ilmu pendidikan, terutama pada muatan pembelajaran matematika di tingkat sekolah dasar yang sesuai dengan tuntutan kurikulum 2013. Dalam pembelajaran matematika menggunakan sinergi project based learning dan pembelajaran bermakna ini sudah mencakup kelima unsur pendekatan saintifik (mengamati, menanya, mengumpulkan informasi, mengolah informasi, mengkomunikasikan). Hal ini relevan dengan pendapat Mawardi (2014: 116-117) tentang pengintegrasian pendekatan saintifik dengan model pembelajaran inovatif, sintak model project based learning telah terintegrasi dengan komponen pendekatan saintifik, meliputi unsur mengamati dan menanya pada tahap menentukan pertanyaan mendasar, unsur menanya pada tahap menyusun perencanaan projek, unsur mengumpulkan informasi pada tahap menyusun penjadwalan serta tahap memonitor peserta didik dan kemajuan projek, unsur mengolah informasi dan mengkomunikasikan pada tahap menilai hasil projek, serta unsur mengkomunikasika pada tahap evaluasi pengalaman.

Selain itu, juga dapat melatih peserta didik dalam meningkatkan kemampuan 4C (Creativity, Critical Thinking, Colaborative, Communication). Hal ini sependapat dengan Purbosari (2016: 232) yang menyatakan bahwa pelaksanaan project based learning cukup potensial untuk membantu peserta didik memenuhi tuntutan belajarnya dan dapat menghasilkan suatu produk. Bagian yang tak kalah penting adalah terwujudnya peserta didik yang memenuhi kriteria HOTS (High Thinking Order Skills). Untuk mewujudkan peserta didik yang HOTS, perlu halnya untuk dimulai dari guru yang HOTS terlebih dahulu. Guru merancang pembelajaran sesuai kompetensi dasar dan tujuan yang hendak dicapai dan menentukan indikator dengan tingkatan HOTS, yaitu menganalisis, mengevaluasi, dan mencipta.

Pembelajaran juga bersifat menemukan dan membangun pengetahuannya sendiri. Selain pada domain pengetahuan dan keterampilan, pembelajaran ini membantu menerapkan Penguatan Pendidikan Karakter (PPK). Penguatan pendidikan karakter dalam pembelajaran matematika dapat 
dilaksanakan melalui pembelajaran project based learning. Indrasari (2017: 105) menyatakan bahwa peserta didik dapat belajar menyelesaikan projek dan secara tidak langsung akan muncul penanaman nilai-nilai karakter yang ada di dalam kegiatan pembelajaran. Dampak instruksional yang ingin dicapai berupa keterampilan peserta didik dalam bekerjasama, melatih kedisiplinan, dan tanggung jawab. Di samping dampak tersebut, pembelajaran memberikan pelatihan untuk menumbuhkan sikap demokratis, berani, dan jiwa kepimpinan peserta didik.

Maka dari itu, peneliti menerapakan sinergi project based learning dan pembelajaran bermakna agar tidak hanya hasil belajar saja yang meningkat namun pembelajaran juga bermakna bagi peserta didik. Agar materi yang dibangun berdasarkan pengalaman belajarnya sendiri dapat menjadi bagian penting yang akan selalu diingat oleh peserta didik.

\section{SIMPULAN DAN SARAN}

Sinergi project based learning dan pembelajaran bermakna dapat meningkatkan hasil belajar matematika. Hal tersebut ditunjukkan pada ketuntasan hasil belajar matematika peserta didik pada siklus 1 sebesar 72,5\% dan mengalami peningkatan pada siklus 2 menjadi 80\%. Selain itu, sinergi project based learning dan pembelajaran bermakna memberikan dampak positif bagi guru dan peserta didik, antaralain peserta didik bersemangat dalam mengikuti pembelajaran matematika, kreativitas peserta didik terbangun dengan adanya projek yang harus mereka kerjakan, meningkatnya kemampuan mengorganisir kelompok karena peserta didik harus dapat mengatur pembagian tugas agar projek dapat terselesaikan dengan baik, menumbuhkan jiwa kompetitif antar peserta didik supaya menjadi kelompok yang terbaik, serta pembelajaran lebih bermakna dan memberikan arti mendalam bagi peserta didik dan guru.

Berdasarkan simpulan di atas, sinergi project based learning dan pembelajaran bermakna dapat diterapkan dalam pembelajaran matematika di sekolah dasar. Karena memenuhi tuntutan pembelajaran Kurikulum 2013 yang meliputi pendekatan saintifik, 4C, HOTS, dan PPK. Untuk didapatkan hasil yang lebih maksimal diperlukan persiapkan lebih matang.

\section{UCAPAN TERIMAKASIH}

Penulis mengucapkan terimakasih kepada kedua orangtua, keluarga, kemenristekdikti, almamater, kepala sekolah, peserta didik, dan Sri Redjeki, S.Pd. sebagai guru kelas 4 SDN Gendongan 02.

\section{DAFTAR PUSTAKA}

Aisyah, D. W., Gipayana, M., \& Djatmika, E. T. (2017, June). Mengembangkan Kebermaknaan Belajar Dengan Rancangan Pembelajaran Tematik Bercirikan Quantum Teching. In Prosiding Seminar Nasional Mahasiswa Kerjasama Direktorat Jenderal Guru dan Tenaga Kependidikan Kemendikbud 2016.

Bloom, B.S., Engelhart, M.D., Furst, E.J., Hill, W.H., dan Krathwohl, D.R. 1956. The Taxonomy of Educational Objectives The Classification of Educational Goals, Handbook I: Cognitive Domain. New York: David McKay.

George Lucas Educational Foundation. 2007. Project-Based Learning. Diakses pada Sabtu, 14 April 2018 pukul 08:41 melalui https://www.edutopia.org/project-based-learning-guideimplementation.

Harpaz, Yoram. 2000. Meaningful Learning Internal and External Conditions.

Hosnan. 2014. Pendekatan Saintifik dan Kontekstual dalam Pembelajaran Abad 21. Jakarta: Ghalia Indonesia.

Indasari, M. (2018). Mendidik Karakter Anak melalui Model Pembelajaran Berbasis Projek (Sebuah Desain Pembelajaran Matematika yang Berkarakter). Scholaria: Jurnal Pendidikan dan Kebudayaan, 8(1), 105-108. 
Sinergi Project Based Learning dan Pembelajaran Bermakna Untuk Meningkatkan Hasil Belajar Matematika (Nuning Setyowati, Mawardi)

Joyce, Bruce, Marsha Weil dan Emily Calhoun. 2009. Models of Teaching (Model-model Pengajaran). Jakarta: Pustaka Pelajar.

Kemendikbud. 2014. Implementasi Kurikulum 2013. Jakarta: Kemendibud.

Konita, A. P. (2015). The Implementation of Project Based Learning Model Using Concrete Media in Improving Natural Science Learning At The Fourth Grade Students Of SDN Pucung Kidul 03 in The Academic Year Of 2014/2015. Kalam Cendekia PGSD Kebumen, 3(1.1).

Mawardi, M. (2014). Pemberlakuan Kurikulum SD/MI Tahun 2013 dan Implikasinya terhadap Upaya Memperbaiki Proses Pembelajaran Melalui PTK. Scholaria: Jurnal Pendidikan dan Kebudayaan, 4(3), 107-121.

Marshall, L., \& Swan, P. (2008). Exploring the use of mathematics manipulative materials: Is it what we think it is?.

Mulyasa. 2015. Pengembangan dan Implementasi Kurikulum 2013. Bandung: PT Remaja Rosdakarya.

Mutaqin, M. 2014. Implementasi Pembelajaran Karakter dalam Pembelajaran Berbasis Projek untuk Meningkatkan Soft Skill Mahasiswa. Jurnal Pendidikan Karakter, 4 (2), 185-199.

Nurfitriyanti, M. (2016). Model Pembelajaran Project Based Learning terhadap Kemampuan Pemecahan Masalah Matematika. Formatif, 6(2), 149-160.

Permendikbud No. 24 Tahun 2016 tentang Kompetensi Inti dan Kompetensi Dasar.

Permendikbud No. 21 Tahun 2016 tentang Standar Isi.

Purbosari, P. M. (2016). Pembelajaran berbasis projek membuat ensiklopedia Ilmu Pengetahuan Alam (IPA) untuk meningkatkan academic skill pada mahasiswa. Scholaria: Jurnal Pendidikan dan Kebudayaan, 6(3), 231-238.

Rahmawati, H., \& Noviana, E. (2016). Penerapan Model Project Based Learning untuk Meningkatkan Hasil Belajar Matematika Siswa Kelas V SD Negeri 018 Sungai Keranji. Jurnal Online Mahasiswa (JOM) Bidang Keguruan dan Ilmu Pendidikan, 3(2), 1-10.

Rais, Muth. 2010. Project Based Learning: Inovasi Pembelajaran yang Berorientasi Soft Skills. Universitas Negeri Surabaya.

Ramadhany, A., Purnomo, A., \& Suryadi, A. (2016). Pengaruh Penggunaan Model Pembelajaran Project Based Learning pada Pembelajaran Sejarah Terhadap Hasil Belajar Siswa Kelas XI IPS MAN Temanggung. Indonesian Journal of History Education, 4(2), 14-20.

Ridho, Nur. 2011. Pembelajaran Bermakna.

Rifa'i, Achmad dan Catharina Tri Anni. 2012. Psikologi Pendidikan. Semarang: Pusat Pengembangan MKU/MKDK-LP3 Universitas Negeri Semarang.

Sani, Ridwan Abdullah. 2014. Pembelajaran Saintifik untuk Implementasi Kurikulum 2013. Jakarta: Bumi Aksara.

Sari, L. I., Satrijono, H., \& Sihono, S. (2015). Penerapan Model Pembelajaran Berbasis Projek (Project Based Learning) untuk Meningkatkan Hasil Belajar Keterampilan Berbicara Siswa Kelas VA SDN Ajung 03. Jurnal Edukasi, 2(1), 11-14.

Sitaresmi, K. S., Saputro, S., \& Utomo, S. B. (2017). Penerapan Pembelajaran Project Based Learning (Pjbl) Untuk Meningkatkan Aktivitas Dan Prestasi Belajar Siswa Pada Materi Sistem Periodik Unsur (Spu) Kelas X Mia 1 SMA Negeri 1 Teras Boyolali Tahun Pelajaran 2015/2016. Jurnal Pendidikan Kimia, 6(1), 54-61.

Sundayana, Rostina. 2015. Media dan Alat Peraga dalam Pembelajaran Matematika. Bandung: Alfabeta.

Suprijono, Agus. 2012. Cooperative Learning. Yogyakarta: Pustaka Pelajar. 
Susanto, Ahmad. 2013. Teori Belajar dan Pembelajaran di Sekolah Dasar. Jakarta: Kencana.

Tafakur, T., \& Suyanto, W. (2015). Pengaruh Cooperative Project-Based Learning terhadap Motivasi dan Hasil Belajar Praktik "Perbaikan Motor Otomotif" Di SMKN 1 Seyegan. Jurnal Pendidikan Vokasi, 5(1), 117-131.

Thomas, J. W. (2000). A review of research on project-based learning.

Umi, U. (2015). Penerapan Pendekatan Saintifik melalui Model Project Based Learning untuk Meningkatkan Ketrampilan Proses dan Hasil Belajar Siswa Kelas IV SD Negeri Seworan, Wonosegoro. Scholaria: Jurnal Pendidikan dan Kebudayaan, 5(1), 24-38. 